\title{
The Partial Pressure of Resting End-Tidal Carbon Dioxide Predicts Major Cardiac Events In Patients with Systolic Heart Failure
}

\author{
Ross Arena, PhD, $\mathrm{PT}^{1}$, Jonathan Myers, $\mathrm{PhD}^{2}$, Joshua Abella, $\mathrm{MD}^{2}$, Sherry Pinkstaff, $\mathrm{DPT}^{1}$, \\ Peter Brubaker, PhD $^{3}$, Brian Moore, MS $^{3}$, Dalane Kitzman, MD $^{3}$, Mary Ann Peberdy, MD $^{4}$, \\ Daniel Bensimhon, MD ${ }^{5}$, Paul Chase, Med ${ }^{5}$, and Marco Guazzi, MD, PhD ${ }^{6}$ \\ ${ }^{1}$ Department of Physical Therapy, Virginia Commonwealth University, Health Sciences Campus, \\ Richmond, Virginia \\ 2VA Palo Alto Health Care System, Cardiology Division, Stanford University, Palo Alto, CA \\ ${ }^{3}$ Wake Forrest University School of Medicine, Cardiology Section, Winston-Salem, NC \\ ${ }^{4}$ Department of Internal Medicine, Virginia Commonwealth University, Richmond, Virginia \\ ${ }^{5}$ LeBauer Cardiovascular Research Foundation, Greensboro, NC \\ ${ }^{6}$ University of Milano, San Paolo Hospital, Cardiopulmonary Laboratory, Cardiology Division, \\ University of Milano, San Paolo Hospital, Milano, Italy
}

\begin{abstract}
Background-The resting partial pressure of end tidal carbon dioxide $\left(\mathrm{P}_{\mathrm{ET}} \mathrm{CO}_{2}\right)$ has been shown to reflect cardiac performance in acute care settings in patients with heart failure (HF). The purpose of the present study was to compare the prognostic ability of the partial pressure of $\mathrm{P}_{\mathrm{ET}} \mathrm{CO}_{2}$ at rest to other commonly collected resting variables in patients with systolic HF.

Methods-A total of 353 patients (mean age: $58.6 \pm 13.7,72 \%$ male) with systolic HF were included in this study. All patients underwent cardiopulmonary exercise testing where NYHA class, resting $\mathrm{P}_{\mathrm{ET}} \mathrm{CO}_{2}$, peak oxygen consumption $\left(\mathrm{VO}_{2}\right)$ and the minute ventilation/carbon dioxide production $\left(\mathrm{VE} / \mathrm{VCO}_{2}\right)$ slope were determined. Subjects were then followed for major cardiac events (mortality, LVAD implantation, urgent heart transplantation).
\end{abstract}

Results-There were one hundred and four major cardiac events during the $23.6 \pm 17.0$ month tracking period. Multivariate Cox regression analysis revealed NYHA class (Chi-square: 28.7, $\mathrm{p}<0.001$ ), LVEF (Residual chi-square: 21.7, $\mathrm{p}<0.001$ ) and resting $\mathrm{P}_{\mathrm{ET}} \mathrm{CO}_{2}$ (Residual chi-square: $14.1, \mathrm{p}<0.001)$ were all prognostically significant and retained in the regression. In a separate Cox regression analysis, LVEF (residual chi-square: $8.8, \mathrm{p}=0.003$ ), NYHA class (residual chi-square: 7.7, $\mathrm{p}=0.005$ ) and resting $\mathrm{P}_{\mathrm{ET}} \mathrm{CO}_{2}$ (residual chi-square: 5.7, $\mathrm{p}=0.02$ ) added prognostic value to the $\mathrm{VE} / \mathrm{VCO}_{2}$ slope (Chi-square: 26.0, $\left.\mathrm{p}<0.001\right)$.

\footnotetext{
(C) 2008 Mosby, Inc. All rights reserved.

Address for correspondence: Ross Arena, PhD, PT, Associate Professor, Department of Physical Therapy, Box 980224, Virginia Commonwealth University, Health Sciences Campus, Richmond, VA USA 23298-0224 804-828-0234, office raarena@.vcu.edu. Publisher's Disclaimer: This is a PDF file of an unedited manuscript that has been accepted for publication. As a service to our customers we are providing this early version of the manuscript. The manuscript will undergo copyediting, typesetting, and review of the resulting proof before it is published in its final citable form. Please note that during the production process errors may be discovered which could affect the content, and all legal disclaimers that apply to the journal pertain.
} 
Conclusion-Resting $\mathrm{P}_{\mathrm{ET}} \mathrm{CO}_{2}$ can be non-invasively collected from subjects in a short period of time, at a low cost and with no risk or discomfort to the patient. Given the prognostic value demonstrated in the present study, the clinical assessment of resting $\mathrm{P}_{\mathrm{ET}} \mathrm{CO}_{2}$ in the HF population may be warranted.

\section{Keywords}

Ventilatory expired gas; cardiac events; outcomes

\section{Introduction}

Ventilatory expired gas analysis during aerobic exercise testing clearly provides prognostic value in the heart failure (HF) population.(1) The predictive value of ventilatory efficiency and aerobic capacity is a function of their relationships with other measures of pathophysiology and disease severity in this population. While a great deal of attention has been devoted to measures obtained during exercise, particularly peak oxygen consumption $\left(\mathrm{VO}_{2}\right)$ and the minute ventilation/carbon dioxide production $\left(\mathrm{VE} / \mathrm{VCO}_{2}\right)$ slope, little focus has been directed towards the clinical value of resting ventilatory expired gas analysis. The partial pressure of resting end-tidal carbon dioxide $\left(\mathrm{P}_{\mathrm{ET}} \mathrm{CO}_{2}\right)$ is one such variable that may provide important clinical information, particularly given its previously demonstrated relationship to cardiac function in other patient populations.(2-10) Furthermore, Matsumoto et al.(11) found significantly lower resting $\mathrm{P}_{\mathrm{ET}} \mathrm{CO}_{2}$ values in $\mathrm{HF}$ patients with a higher NYHA class, indicating a link between this expired gas variable and an established clinical measure of disease severity.

To our knowledge, we are the only research group to previously report on the reliability(12) and prognostic significance of resting $\mathrm{P}_{\mathrm{ET}} \mathrm{CO}_{2}$ in patients with HF.(13) In the prior analysis, we found resting $\mathrm{P}_{\mathrm{ET}} \mathrm{CO}_{2}$ was a significant univariate predictor of adverse events in a small HF cohort ( $\mathrm{n}=121)$, with the majority of events being cardiac-related hospitalization, over only a one-year tracking period. Furthermore, resting $\mathrm{P}_{\mathrm{ET}} \mathrm{CO}_{2}$ added prognostic value to other resting and exercise variables in a multivariate analysis. While these previous results are compelling, more work in this area is required to corroborate and expand upon our initial findings. The purpose of the present investigation is to therefore examine the ability of resting $\mathrm{P}_{\mathrm{ET}} \mathrm{CO}_{2}$ to predict cardiac mortality, left ventricular assist device implantation (LVAD) and urgent heart transplantation, all hard endpoints, in a large HF cohort over an extended tracking period.

\section{Methods}

This study is a multi-center analysis including HF patients from the exercise testing laboratories at San Paolo Hospital, Milan, Italy Wake Forrest University Baptist Medical Center, Winston-Salem, North Carolina and Virginia Commonwealth University, Richmond, Virginia, USA. A total of 353 patients with chronic HF, secondary to systolic dysfunction, were included. Inclusion criteria consisted of a diagnosis of $\mathrm{HF}(14)$ and evidence of left ventricular systolic dysfunction by two-dimensional echocardiography [left ventricular ejection fraction (LVEF) $\$ 40 \%$ ] obtained within one month of data collection. Furthermore, none of the subjects included in this analysis suffered from arterial hypoxemia or had a previous diagnosis of pulmonary disease or pulmonary embolism as per medical chart review. Subjects from Virginia Commonwealth University assessed in the original resting $\mathrm{P}_{\mathrm{ET}} \mathrm{CO}_{2}$ investigation by our group, described in the introduction(13), were also included in this analysis. All subjects completed a written informed consent and institutional review board approval was obtained at each institution. 
Ventilatory expired gas analysis was performed using a metabolic cart at all three centers (Medgraphics CPX-D, Minneapolis, MN or Sensormedics Vmax29, Yorba Linda, CA). Before each test, the equipment was calibrated in standard fashion using reference gases and a three-liter syringe. Prior to symptom-limited exercise testing, ventilatory expired gas data was collected at rest in the seated position for two minutes. The subject was allowed to adjust to the mouthpiece for a minimum of 30 seconds before resting data collection was initiated. The partial pressure of end-tidal carbon dioxide (in $\mathrm{mmHg}$ ) and the minute ventilation (VE)/carbon dioxide production $\left(\mathrm{VCO}_{2}\right)$ ratio at rest were both expressed as twominute averaged values. Resting respiratory exchange ratio (RER) was monitored to ensure subjects were not hyperventilating at rest and data was only collected when resting RER was below 1.0 for the entire two-minutes (average $=0.87$ ). All subjects then underwent a symptom-limited exercise test using a conservative ramping protocol. Peak oxygen consumption $\left(\mathrm{VO}_{2}\right)$, the minute ventilation $(\mathrm{VE}) /$ carbon dioxide production $\left(\mathrm{VCO}_{2}\right)$ slope, $\mathrm{P}_{\mathrm{ET}} \mathrm{CO}_{2}$ at ventilatory threshold (VT)(15), the change in $\mathrm{P}_{\mathrm{ET}} \mathrm{CO}_{2}$ from rest to VT $\left(\mathrm{P}_{\mathrm{ET}} \mathrm{CO}_{2 \text { Delta }}\right)$ and $\mathrm{P}_{\mathrm{ET}} \mathrm{CO}_{2}$ at peak exercise were also determined for this analysis. Peak $\mathrm{VO}_{2} \mathrm{P}_{\mathrm{ET}} \mathrm{CO}_{2}$ at VT, $\mathrm{P}_{\mathrm{ET}} \mathrm{CO}_{2}$ at peak exercise and $\mathrm{P}_{\mathrm{ET}} \mathrm{CO}_{2 \text { Delta }}$ were all expressed as 10second averaged sample obtained during the exercise test. Percent-predicted peak $\mathrm{VO}_{2}$ was calculated using the equations derived by Wasserman et al.(16) $\mathrm{VE}$ and $\mathrm{VCO}_{2}$ values, acquired from the initiation of exercise to peak, were input into spreadsheet software (Microsoft Excel, Microsoft Corp., Bellevue, WA) to calculate the $\mathrm{VE} / \mathrm{VCO}_{2}$ slope via least squares linear regression $(\mathrm{y}=\mathrm{mx}+\mathrm{b}, \mathrm{m}=$ slope $)$.

Subjects were followed for major cardiac events (mortality, LVAD implantation, urgent heart transplantation) via hospital and outpatient medical chart review for a four year period. Subjects were followed by the HF programs at their respective institution providing a high likelihood that all events were captured. Any death with a cardiac-related discharge diagnosis was considered an event. Clinicians conducting the exercise test were not involved in decisions regarding cause of death or urgent heart transplant/LVAD implantation.

All continuous data are reported as mean values \pm standard deviation (SD). Pearson Product moment correlation assessed the relationship between resting $\mathrm{P}_{\mathrm{ET}} \mathrm{CO}_{2}$ and other continuous variables included in this analysis (age, $\mathrm{LVEF}$, resting $\mathrm{VE} / \mathrm{VCO}_{2}$, peak $\mathrm{VO}_{2}, \mathrm{P}_{\mathrm{ET}} \mathrm{CO}_{2}$ at ventilatory threshold, $\mathrm{P}_{\mathrm{ET}} \mathrm{CO}_{2 \text { Delta }}, \mathrm{P}_{\mathrm{ET}} \mathrm{CO}_{2}$ at peak exercise and the $\mathrm{VE} / \mathrm{VCO}_{2}$ slope). A correlation analysis between the $\mathrm{VE} / \mathrm{VCO}_{2}$ slope and both resting $\mathrm{VE} / \mathrm{VCO}_{2}$ and $\mathrm{P}_{\mathrm{ET}} \mathrm{CO}_{2}$ measurements during exercise was also performed. One-way analysis of variance assessed differences in resting $\mathrm{P}_{\mathrm{ET}} \mathrm{CO}_{2}$ amongst NYHA classes I, II and III/IV (III/IV combined secondary to the low number of subjects in the latter NYHA class). Tukey's honestly significant difference was used to determine differences in subgroups when the one-way ANOVA p-value was $<0.05$. Univariate and multivariate (forward stepwise method, entry and removal values 0.05 and 0.10 , respectively) Cox regression analysis assessed the prognostic characteristics of LVEF, resting $\mathrm{P}_{\mathrm{ET}} \mathrm{CO}_{2}$, NYHA class, age and HF etiology. The combined prognostic value of LVEF, resting $\mathrm{P}_{\mathrm{ET}} \mathrm{CO}_{2}$ and exercise variables (peak $\mathrm{VO}_{2}$, $\mathrm{P}_{\mathrm{ET}} \mathrm{CO}_{2 \text { Delta }}$ and the $\mathrm{VE} / \mathrm{VCO}_{2}$ slope) was also assessed. Measures of $\mathrm{P}_{\mathrm{ET}} \mathrm{CO}_{2}$ at ventilatory threshold and peak exercise were not included in the survival analysis secondary to collinearity with resting $\mathrm{P}_{\mathrm{ET}} \mathrm{CO}_{2}$ (see correlation analysis in the results). Kaplan-Meier analysis was used to assess survival characteristics of dichotomous expressions of resting variables retained in the multivariate regression analyses both separately and in combination. Kaplan-Meier analysis was also used to assess the combined prognostic value of resting and cardiopulmonary exercise test variables retained in a multivariate regression analysis. The log-rank test determined statistical significance of the Kaplan-Meier analysis. Statistical differences with a p-value $<0.05$ were considered significant. 


\section{Results}

Subject characteristics are listed in Table 1 . The majority of this cohort was male, NYHA class II or III and prescribed both an ACE inhibitor and diuretic. The mechanism of HF was balanced between ischemic and non-ischemic etiology. Mean resting $\mathrm{P}_{\mathrm{ET}} \mathrm{CO}_{2}$ and peak $\mathrm{VO}_{2}$ were lower and the $\mathrm{VE} / \mathrm{VCO}_{2}$ slope was elevated compared to expected responses in apparently healthy individuals. The correlation between resting $\mathrm{P}_{\mathrm{ET}} \mathrm{CO}_{2}$ and $\mathrm{LVEF}(\mathrm{r}=$ $0.17, \mathrm{p}=0.001)$, resting VE/ $/ \mathrm{VCO}_{2}(\mathrm{r}=-0.43, \mathrm{p}<0.001), \mathrm{P}_{\mathrm{ET}} \mathrm{CO}_{2}$ at $\mathrm{VT}(\mathrm{r}=0.84, \mathrm{p}<0.001)$, $\mathrm{P}_{\mathrm{ET}} \mathrm{CO}_{2}$ at peak exercise $(\mathrm{r}=0.78, \mathrm{p}<0.001)$, peak $\mathrm{VO}_{2}(\mathrm{r}=0.21, \mathrm{p}<0.001)$ and the VE/ $\mathrm{VCO}_{2}$ slope $(\mathrm{r}=-0.51, \mathrm{p}=0.001)$ were statistically significant while the relationship with age $(\mathrm{r}=-0.07, \mathrm{p}=0.19)$ and $\mathrm{P}_{\mathrm{ET}} \mathrm{CO}_{2 \text { Delta }}(\mathrm{r}=-0.03, \mathrm{p}=0.60)$ were not. Moreover, the correlation between the $\mathrm{VE} / \mathrm{VCO}_{2}$ slope and resting $\mathrm{VE} / \mathrm{VCO}_{2}(\mathrm{r}=0.59, \mathrm{p}<0.001), \mathrm{P}_{\mathrm{ET}} \mathrm{CO}_{2}$ at VT $(\mathrm{r}=-0.60, \mathrm{p}<0.001), \mathrm{P}_{\mathrm{ETCO}}$ at peak exercise $(\mathrm{r}=0.75, \mathrm{p}<0.001)$ and $\mathrm{P}_{\mathrm{ET}} \mathrm{CO}_{2 \text { Delta }}(\mathrm{r}$ $=-0.31, \mathrm{p}<0.001$ ) were all statistically significant. Mean resting $\mathrm{P}_{\mathrm{ET}} \mathrm{CO}_{2}$ values for subjects in NYHA class I, II and III/IV were $35.6 \pm 3.6,34.6 \pm 3.6$ and $33.7 \pm 4.3 \mathrm{mmHg}$, respectively. Post-hoc analysis revealed that while the difference in resting $\mathrm{P}_{\mathrm{ET}} \mathrm{CO}_{2}$ values between NYHA class II and III/IV approached a p-value $<0.05$ ( $\mathrm{p}=0.09)$, only differences between NYHA class I and III/IV reached statistical significance $(\mathrm{p}=0.01)$.

There were 104 major cardiac events (92 deaths, 3 LVAD implantations and 9 urgent heart transplantations) during the mean $23.6 \pm 17.0$ month tracking period. The annual event rate was $13.3 \%$. Cox regression results for resting variables are listed in Table 2. NYHA class, LVEF and resting $\mathrm{P}_{\mathrm{ET}} \mathrm{CO}_{2}$ were all prognostically significant univariate markers and retained in the multivariate regression. Neither age nor $\mathrm{HF}$ etiology were significant predictors of risk. NYHA, LVEF and resting $\mathrm{P}_{\mathrm{ET}} \mathrm{CO}_{2}$ were again retained in the multivariate Cox regression when cardiac-related mortality was the only event considered.

For Kaplan-Meier analysis, dichotomous thresholds of $\leq />25 \%, \leq />33 \mathrm{mmHg}$ and I/II vs. III/IV were set for LVEF(14), resting $\mathrm{P}_{\mathrm{ET}} \mathrm{CO}_{2}(13)$ and NYHA class, respectively. Hazard ratios for the NYHA class, $\mathrm{LVEF}$ and resting $\mathrm{P}_{\mathrm{ET}} \mathrm{CO}_{2}$ were 2.20 (95\% CI: 1.49-3.26, $\mathrm{p}<0.001), 2.26$ (95\% CI: 1.54-3.33, p<0.001) and 2.17 (95\% CI: 1.48-3.19, p<0.001), respectively. The independent prognostic characteristics of these dichotomous thresholds are illustrated in Figure 1. Using these thresholds, there was a significant difference in event rates between groups. Figure 2 illustrates event-free survival characteristics when these thresholds for resting $\mathrm{P}_{\mathrm{ET}} \mathrm{CO}_{2}$, LVEF and NYHA class were considered collectively. This latter approach improved the accuracy of identifying low (no abnormal values) and high-risk ( 3 abnormal values) groups. Furthermore, use of all three resting variables allowed for the identification of subjects at intermediate risk (1-2 negative values).

In a separate Cox regression analysis including exercise test variables, the $\mathrm{VE} / \mathrm{VCO}_{2}$ slope (Threshold </ 36.0 ; chi-square: 26.0, p $<0.001$ ), LVEF (Threshold $\leq />25 \%$; chi-square: 18.0, $\mathrm{p}<0.001$ ), resting $\mathrm{P}_{\mathrm{ET}} \mathrm{CO}_{2}$ (Threshold $\leq />33 \mathrm{mmHg}$; chi-square: 16.3 , $\mathrm{p}<0.001$ ), NYHA class (Threshold I/II vs. III/IV; chi-square 16.3, p <0.001), peak $\mathrm{VO}_{2}($ Threshold $</ \geq$ $14 \mathrm{mlO}_{2} \bullet \mathrm{kg}^{-1} \cdot \min ^{1}$; chi-square: $\left.7.4, \mathrm{p}=0.006\right)$ and $\mathrm{P}_{\mathrm{ET}} \mathrm{CO}_{2 \text { Delta }}$ (Threshold $</ \geq 2 \mathrm{mmHg}$; chi-square: $3.9, \mathrm{p}=0.047$ ) were all significant univariate predictors of major cardiac events. Left ventricular ejection fraction (residual chi-square: $8.8, \mathrm{p}=0.003$ ), NYHA class (residual chi-square: 7.7, $\mathrm{p}=0.005$ ), resting $\mathrm{P}_{\mathrm{ET}} \mathrm{CO}_{2}$ (residual chi-square: 5.7, $\mathrm{p}=0.02$ ), but not $\mathrm{P}_{\mathrm{ET}} \mathrm{CO}_{2 \text { Delta }}$ (residual chi-square: $0.53, \mathrm{p}=0.47$ ) or peak $\mathrm{VO}_{2}$ (residual chi-square: 0.02, $\mathrm{p}=0.90$ ), added prognostic value to the $\mathrm{VE} / \mathrm{VCO}_{2}$ slope in a multivariate model. A second Kaplan-Meier analysis, illustrated in Figure 3, considered the $\mathrm{VE} / \mathrm{VCO}_{2}$ slope in addition to NYHA class, $\mathrm{LVEF}$ and resting $\mathrm{P}_{\mathrm{ET}} \mathrm{CO}_{2}$. Assessment of this cardiopulmonary exercise test variable, in conjunction with resting measures, further improved risk stratification. 


\section{Discussion}

Our group previously demonstrated resting $\mathrm{P}_{\mathrm{ET}} \mathrm{CO}_{2}$ was a significant predictor of cardiac events in 121 subjects with HF.(13) In this relatively small analysis, the majority of recorded events were hospitalization secondary to decompensated HF (41 of 50), a soft endpoint. While the initial findings were compelling, confirmation was required in a larger cohort with a hard composite endpoint. The results of the present study, using hard endpoints (death, urgent transplantation or LVAD implant), further affirm the prognostic value of resting $\mathrm{P}_{\mathrm{ET}} \mathrm{CO}_{2}$ in combination with other baseline measures with well-established prognostic value [NYHA class(17-20), LVEF(20-22)]. Moreover, resting variables, including resting $\mathrm{P}_{\mathrm{ET}} \mathrm{CO}_{2}$, were prognostically superior to peak $\mathrm{VO}_{2}$ and added predictive value to the VE/ $\mathrm{VCO}_{2}$ slope. While peak $\mathrm{VO}_{2}$ is still most frequently considered for prognostic purposes, evidence demonstrating other ventilatory expired gas measures, such as the $\mathrm{VE} / \mathrm{VCO}_{2}$ slope(23) and now resting $\mathrm{P}_{\mathrm{ET}} \mathrm{CO}_{2}$, may provide superior predictive information. The measurement and clinical consideration of resting $\mathrm{P}_{\mathrm{ET}} \mathrm{CO}_{2}$ may therefore be warranted during resting evaluations and in combination with cardiopulmonary exercise testing.

Carbon dioxide elimination, and therefore $\mathrm{P}_{\mathrm{ET}} \mathrm{CO}_{2}$, decreases when blood flow to the lungs is reduced. Numerous investigations have demonstrated a significant relationship between resting $\mathrm{P}_{\mathrm{ET}} \mathrm{CO}_{2}$ and cardiac output.(2-10) Shibutani et al.(10) found $\mathrm{P}_{\mathrm{ET}} \mathrm{CO}_{2}$ was significantly correlated with changes in cardiac output during surgery $\left(\mathrm{r}^{2}=0.82, \mathrm{p}<0.01\right)$ in patients undergoing abdominal aortic aneurysm repair. Wahba et al.(7) reported $\mathrm{P}_{\mathrm{ET}} \mathrm{CO}_{2}$ was effectively able to detect changes in cardiac index $(r=0.75, \mathrm{p}<0.001)$ in subjects undergoing open heart surgery. Lastly, in a group of 100 critically ill surgery patients, Domsky et al.(24) reported a 55\% mortality rate in patients with a $\mathrm{P}_{\mathrm{ET}} \mathrm{CO}_{2}$ less than or equal to $28 \mathrm{mmHg}$. This is compared to a $17 \%$ mortality rate for those patients with a $\mathrm{P}_{\mathrm{ET}} \mathrm{CO}_{2}$ greater than $28 \mathrm{mmHg}$. While none of these investigations were performed in patients with $\mathrm{HF}$, they do provide a basis for the notion that resting $\mathrm{P}_{\mathrm{ET}} \mathrm{CO}_{2}$ provides some reflection of varying degrees of cardiac output/function and therefore possesses prognostic value in this patient population. The results of the present study and our previous investigation ${ }^{13}$ appear to support this hypothesis as it relates to the prognostic value of resting $\mathrm{P}_{\mathrm{ET}} \mathrm{CO}_{2}$.

Mechanisms other than cardiac function for a diminished resting $\mathrm{P}_{\mathrm{ET}} \mathrm{CO}_{2}$ in advanced $\mathrm{HF}$ are, however, highly plausible and must be considered. Previous investigations have demonstrated physiologic dead space ventilation continues to increase while the partial pressure of carbon dioxide in arterial blood continues to decline as HF severity progresses. $(25 ; 26)$ Both of these physiologic abnormalities, either independently or synergistically, can also lead to a reduction in resting $\mathrm{P}_{\mathrm{ET}} \mathrm{CO}_{2}$. It is therefore likely that the mechanism for the reduction in resting $\mathrm{P}_{\mathrm{ET}} \mathrm{CO}_{2}$ observed in some patients with $\mathrm{HF}$ is multi-factorial (i.e. reduced cardiac output, reduced partial pressure of carbon dioxide in arterial blood and increased physiologic dead space ventilation) with a continued decline in this resting expired gas variable reflecting higher levels of overall HF severity and worse prognosis. Future research is required to better elucidate the reason(s) why resting $\mathrm{P}_{\mathrm{ET}} \mathrm{CO}_{2}$ is reduced in $\mathrm{HF}$.

Previous investigations have reported that the $\mathrm{VE} / \mathrm{VCO}_{2}$ slope is significantly correlated with other measures reflecting disease severity in HF such as invasively assessed cardiac output and pulmonary hemodynamics(27), brain natriuretic peptide(28), heart rate variability(29) and alveolar-capillary membrane conductance(30). While we were able to demonstrate a significant correlation between resting $\mathrm{P}_{\mathrm{ET}} \mathrm{CO}_{2}$ and the $\mathrm{VE} / \mathrm{VCO}_{2}$, the collection of other disease severity indicators was limited. It would appear that the relationship between LVEF and resting $\mathrm{P}_{\mathrm{ET}} \mathrm{CO}_{2}$, while statistically significant, is rather weak. Likewise, the difference in resting $\mathrm{P}_{\mathrm{ET}} \mathrm{CO}_{2}$ according to NYHA class was only significant between class I and III/IV. Future investigations should be directed toward 
examining the relationship between resting $\mathrm{P}_{\mathrm{ET}} \mathrm{CO}_{2}$ and other objective markers of $\mathrm{HF}$ severity.

Resting $\mathrm{P}_{\mathrm{ET}} \mathrm{CO}_{2}$ is quickly and easily collected at a low cost, making this measure a particularly attractive assessment option in clinical practice. In addition to its prognostic potential, other possible clinical applications for resting $\mathrm{P}_{\mathrm{ET}} \mathrm{CO}_{2}$ include assessing the response to therapeutic interventions and gauging HF stability. Interventions, such as cardiac resynchronization therapy and aerobic exercise training, that result in an improvement in cardiac function(31;32) may also increase resting $\mathrm{P}_{\mathrm{ET}} \mathrm{CO}_{2}$. In this instance, resting $\mathrm{P}_{\mathrm{ET}} \mathrm{CO}_{2}$ may be valuable in distinguishing between responders and non-responders. Furthermore, resting $\mathrm{P}_{\mathrm{ET}} \mathrm{CO}_{2}$ likely declines as a patient with $\mathrm{HF}$ worsens from a compensated to decompensated state. Serial assessment of resting $\mathrm{P}_{\mathrm{ET}} \mathrm{CO}_{2}$ would allow for the rapid detection of declining HF stability, assisting in the formulation of a treatment plan. Future research should be directed toward determining the value of broader clinical applications for resting $\mathrm{P}_{\mathrm{ET}} \mathrm{CO}_{2}$ in patients with $\mathrm{HF}$.

The fact that we collected resting $\mathrm{P}_{\mathrm{ET}} \mathrm{CO}_{2}$ data in a select $\mathrm{HF}$ cohort referred for cardiopulmonary exercise testing is a study limitation. The characteristics of subjects included in the present investigation most likely differ from the HF population seen in the out-patient setting. For example, while patients in NYHA class IV are seen in the clinic, few are referred for exercise testing. To support the broader application of resting $\mathrm{P}_{\mathrm{ET}} \mathrm{CO}_{2}$, our findings must be confirmed in HF patients seen on an out-patient basis, but not necessarily selected to undergo exercise testing. In addition, other resting variables with prognostic value, such as b-type natriuretic peptide $(33 ; 34)$, should be included in the multivariate analyses of subsequent investigations. Lastly, application of our findings to patients with diastolic HF is unknown. Future research should also determine if the prognostic characteristics of resting $\mathrm{P}_{\mathrm{ET}} \mathrm{CO}_{2}$ is similar in patients with diastolic HF.

In conclusion, a diagnosis of HF continues to carry a poor prognosis(35), making the identification of variables with predictive value an important area of study. Resting $\mathrm{P}_{\mathrm{ET}} \mathrm{CO}_{2}$ appears to add prognostic value to variables that are well-established and commonly collected in clinical practice. The fact that resting $\mathrm{P}_{\mathrm{ET}} \mathrm{CO}_{2}$ is easily, cheaply and noninvasively obtained portends high clinical promise for this measurement.

\section{Acknowledgments}

Supported in part by NIH grants R37AG18915 and P60AG10484

\section{Reference List}

1. Arena R, Myers J, Guazzi M. The clinical and research applications of aerobic capacity and ventilatory efficiency in heart failure: an evidence-based review. Heart Fail Rev. 2007; 13:245-269. [PubMed: 17987381]

2. Jin X, Weil MH, Tang W, Povoas H, Pernat A, Xie J, et al. End-tidal carbon dioxide as a noninvasive indicator of cardiac index during circulatory shock. Crit Care Med. 2000; 28(7):24152419. [PubMed: 10921572]

3. Isserles SA, Breen PH. Can changes in end-tidal PCO2 measure changes in cardiac output? Anesth Analg. 1991; 73(6):808-814. [PubMed: 1952183]

4. Idris AH, Staples ED, O'Brien DJ, Melker RJ, Rush WJ, Del Duca KD, et al. End-tidal carbon dioxide during extremely low cardiac output. Ann Emerg Med. 1994; 23(3):568-572. [PubMed: 8135436]

5. Hayashida M, Orii R, Komatsu K, Chinzei M, Nakagawa Y, Nishiyama T, et al. Effects of cardiac output on PETCO2 and PaCO2 during combined inhalational-epidural anesthesia. Masui. 1997; 46(10):1290-1298. [PubMed: 9369041] 
6. Hayashida M, Orii R, Komatsu K, Du HL, Sato Y, Uchida K, et al. Relationship between cardiac output and PETco2 as well as Paco2 during high-dose fentanyl anesthesia. Masui. 1998; 47(2):161167. [PubMed: 9513328]

7. Wahba RW, Tessler MJ, Beique F, Kleiman SJ. Changes in PCO2 with acute changes in cardiac index. Can J Anaesth. 1996; 43(3):243-245. [PubMed: 8829863]

8. Garnett AR, Ornato JP, Gonzalez ER, Johnson EB. End-tidal carbon dioxide monitoring during cardiopulmonary resuscitation. JAMA. 1987; 257(4):512-515. [PubMed: 3098993]

9. Falk JL, Rackow EC, Weil MH. End-tidal carbon dioxide concentration during cardiopulmonary resuscitation. N Engl J Med. 1988; 318(10):607-611. [PubMed: 3125432]

10. Shibutani K, Muraoka M, Shirasaki S, Kubal K, Sanchala VT, Gupte P. Do changes in end-tidal PCO2 quantitatively reflect changes in cardiac output? Anesth Analg. 1994; 79(5):829-833. [PubMed: 7978395]

11. Matsumoto A, Itoh H, Eto Y, Kobayashi T, Kato M, Omata M, et al. End-tidal CO2 pressure decreases during exercise in cardiac patients: association with severity of heart failure and cardiac output reserve. J Am Coll Cardiol. 2000; 36(1):242-249. [PubMed: 10898441]

12. Arena R, Peberdy MA. Reliability of resting end-tidal carbon dioxide in chronic heart failure. J Cardiopulm Rehabil. 2005; 25(3):177-180. [PubMed: 15931023]

13. Arena R, Peberdy MA, Myers J, Guazzi M, Tevald M. Prognostic value of resting end-tidal carbon dioxide in patients with heart failure. Int J Cardiol. 2006; 109(3):351-358. [PubMed: 16046017]

14. Radford MJ, Arnold JM, Bennett SJ, Cinquegrani MP, Cleland JGF, Havranek EP, et al. ACC/ AHA Key Data Elements and Definitions for Measuring the Clinical Management and Outcomes of Patients With Chronic Heart Failure: A Report of the American College of Cardiology/ American Heart Association Task Force on Clinical Data Standards (Writing Committee to Develop Heart Failure Clinical Data Standards): Developed in Collaboration With the American College of Chest Physicians and the International Society for Heart and Lung Transplantation: Endorsed by the Heart Failure Society of America. Circulation. 2005; 112(12):1888-1916. [PubMed: 16162914]

15. Myers, J. Information from Ventilatory Gas Exchange Data. In: Washburn, R., editor. Essentials of Cardiopulmonary Exercise Testing. Champaign: Human Kinetics; 1996. p. 83-108.

16. Wasserman, K.; Hansen, JE.; Sue, DY.; Stringer, W.; Whipp, BJ. Normal Values. In: Weinberg, R., editor. Principles of Exercise Testing and Interpretation. 4. Philadelphia: Lippincott Williams and Wilkins; 2005. p. 160-182.

17. Kerzner R, Gage BF, Freedland KE, Rich MW. Predictors of mortality in younger and older patients with heart failure and preserved or reduced left ventricular ejection fraction*1. American Heart Journal. 2003; 146(2):286-290. [PubMed: 12891197]

18. Davos CH, Doehner W, Rauchhaus M, Cicoira M, Francis DP, Coats AJS, et al. Body mass and survival in patients with chronic heart failure without cachexia: The importance of obesity. Journal of Cardiac Failure. 2003; 9(1):29-35. [PubMed: 12612870]

19. Fappani A, Caprini L, Benedini G, Maggi A, Raddino R, Visioli O. The prognosis of the patient with heart failure: an analysis of the most significant clinical and instrumental parameters. Cardiologia. 1991; 36(6):431-438. [PubMed: 1769026]

20. Francis DP, Shamim W, Davies LC, Piepoli MF, Ponikowski P, Anker SD, et al. Cardiopulmonary exercise testing for prognosis in chronic heart failure: continuous and independent prognostic value from VE/VCO(2)slope and peak VO(2). Eur Heart J. 2000; 21(2):154-161. [PubMed: 10637089]

21. Jankowska EA, Pietruk-Kowalczyk J, Zymlinski R, Witkowski T, Ponikowska B, Sebzda T, et al. The role of exercise ventilation in clinical evaluation and risk stratification in patients with chronic heart failure. Kardiol Pol. 2003; 59(8):115-127. [PubMed: 14560326]

22. Felker GM, Adams KF Jr, Konstam MA, O’Connor CM, Gheorghiade M. The problem of decompensated heart failure: nomenclature, classification, and risk stratification. Am Heart J. 2003; 145(2 Suppl):S18-S25. [PubMed: 12594448]

23. Arena R, Myers J, Abella J, Peberdy MA, Bensimhon D, Chase P, et al. Development of a Ventilatory Classification System in Patients With Heart Failure. Circulation. 2007; 115(18): 2410-2417. [PubMed: 17452607] 
24. Domsky M, Wilson RF, Heins J. Intraoperative end-tidal carbon dioxide values and derived calculations correlated with outcome: prognosis and capnography. Crit Care Med. 1995; 23(9): 1497-1503. [PubMed: 7664551]

25. Wasserman K, Zhang YY, Riley MS. Ventilation during exercise in chronic heart failure. Basic Res Cardiol. 1996; 91 (Suppl 1):1-11. [PubMed: 8896738]

26. Wasserman K, Zhang YY, Gitt A, Belardinelli R, Koike A, Lubarsky L, et al. Lung function and exercise gas exchange in chronic heart failure. Circulation. 1997; 96(7):2221-2227. [PubMed: 9337193]

27. Reindl I, Wernecke KD, Opitz C, Wensel R, Konig D, Dengler T, et al. Impaired ventilatory efficiency in chronic heart failure: possible role of pulmonary vasoconstriction. Am Heart J. 1998; 136(5):778-785. [PubMed: 9812071]

28. Kruger S, Graf Ju, Kunz D, Stickel T, Hanrath P, Janssens U. brain natriuretic peptide levels predict functional capacity in patients with chronic heart failure. Journal of the American College of Cardiology. 2002; 40(4):718-722. [PubMed: 12204502]

29. Ponikowski P, Chua TP, Piepoli M, Banasiak W, Anker SD, Szelemej R, et al. Ventilatory response to exercise correlates with impaired heart rate variability in patients with chronic congestive heart failure. The American Journal of Cardiology. 1998; 82(3):338-344. [PubMed: 9708664]

30. Guazzi M, Reina G, Tumminello G, Guazzi MD. Alveolar-capillary membrane conductance is the best pulmonary function correlate of exercise ventilation efficiency in heart failure patients. Eur $\mathbf{J}$ Heart Fail. 2005; 7(6):1017-1022. [PubMed: 16227140]

31. Seifert M, Schlegl M, Hoersch W, Fleck E, Doelger A, Stockburger M, et al. Functional capacity and changes in the neurohormonal and cytokine status after long-term CRT in heart failure patients. International Journal of Cardiology. 2007; 121(1):68-73. [PubMed: 17582527]

32. Haykowsky MJ, Liang Y, Pechter D, Jones LW, McAlister FA, Clark AM. A Meta-Analysis of the Effect of Exercise Training on Left Ventricular Remodeling in Heart Failure Patients: The Benefit Depends on the Type of Training Performed. Journal of the American College of Cardiology. 2007; 49(24):2329-2336. [PubMed: 17572248]

33. Bergler-Klein J, Klaar U, Heger M, Rosenhek R, Mundigler G, Gabriel H, et al. Natriuretic peptides predict symptom-free survival and postoperative outcome in severe aortic stenosis. Circulation. 2004; 109(19):2302-2308. [PubMed: 15117847]

34. Hartmann F, Packer M, Coats AJS, Fowler MB, Krum H, Mohacsi P, et al. Prognostic Impact of Plasma N-Terminal Pro-Brain Natriuretic Peptide in Severe Chronic Congestive Heart Failure: A Substudy of the Carvedilol Prospective Randomized Cumulative Survival (COPERNICUS) Trial. Circulation. 2004; 110(13):1780-1786. [PubMed: 15381643]

35. American Heart Association. 2007 Heart and Stroke Statistical Update. Dallas, Texas: 2007. Ref Type: Pamphlet 


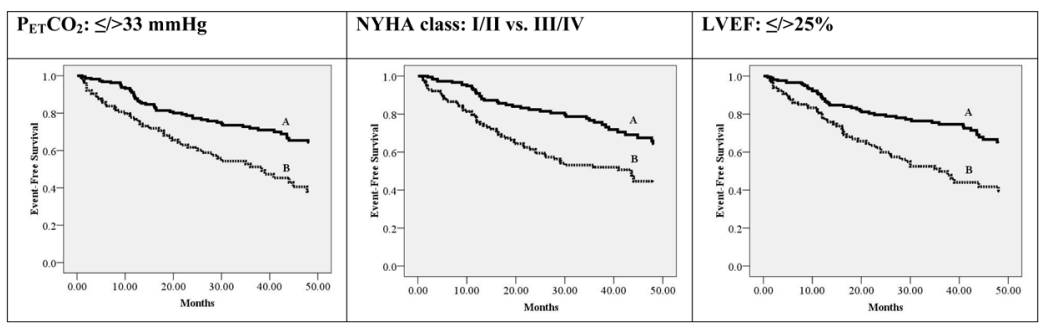

Figure 1.

Individual Kaplan-Meier analyses for LVEF, NYHA class and resting $\mathrm{P}_{\mathrm{ET}} \mathrm{CO}_{2}$ thresholds

\begin{tabular}{|c|c|c|c|c|}
\hline \multicolumn{5}{|c|}{ Resting $\mathrm{P}_{\mathrm{ET}} \mathrm{CO}_{2}: \triangleleft>33 \mathrm{mmHg}$} \\
\hline Group & Characteristics & Subjects meeting criteria & Major Cardiac Events & Percent Event Free \\
\hline $\mathbf{A}$ & $>33 \mathrm{mmHg}$ & 237 & 54 & $77.2 \%$ \\
\hline B & $\leq 33 \mathrm{mmHg}$ & 116 & 50 & $56.9 \%$ \\
\hline \multicolumn{5}{|c|}{ Log rank: $16.3, p<0.001$} \\
\hline \multicolumn{5}{|c|}{ NYHA class: I/II vs. III/IV } \\
\hline Group & Characteristics & Subjects meeting criteria & Major Cardiac Events & Percent Event Free \\
\hline $\mathbf{A}$ & $\mathrm{I} / \mathrm{II}$ & 196 & 41 & $79.1 \%$ \\
\hline B & $\mathrm{III} / \mathrm{IV}$ & 157 & 63 & $59.9 \%$ \\
\hline \multicolumn{5}{|c|}{ Log rank: $16.3, p<0.001$} \\
\hline \multicolumn{5}{|c|}{ LVEF: $\triangleleft>25 \%$} \\
\hline Group & Characteristics & Subjects meeting criteria & Major Cardiac Events & Percent Event Free \\
\hline $\mathbf{A}$ & $>25 \%$ & 216 & 48 & $77.8 \%$ \\
\hline B & 노\% & 137 & 56 & $59.1 \%$ \\
\hline Log ran & $18.0, \mathrm{p}<0.001$ & & & \\
\hline
\end{tabular}




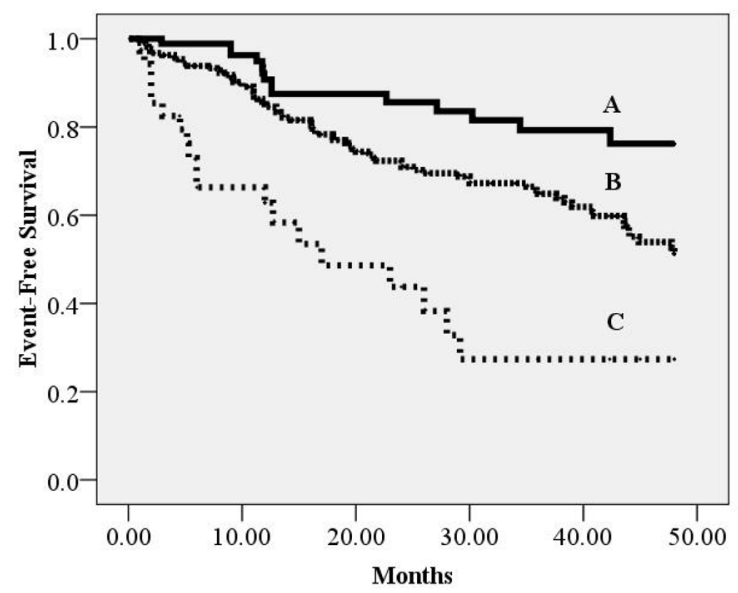

Figure 2.

Kaplan-Meier analysis for combined LVEF, NYHA class and resting $\mathrm{P}_{\mathrm{ET}} \mathrm{CO}_{2}$ thresholds

\begin{tabular}{|l|c|c|c|c|}
\hline Group & Characteristics $^{*}$ & Subjects meeting criteria & Major Cardiac Events & Percent Event Free \\
\hline A & No negative values & 94 & 14 & $85.4 \%$ \\
\hline B & 1-2 Negative Values & 221 & 71 & $67.9 \%$ \\
\hline C & 3 Negative Values & 36 & 19 & $47.2 \%$ \\
\hline
\end{tabular}

Log rank: 29.8, $\mathrm{p}<0.001$

Negative Values:

- $\quad$ Resting PETCO2: $\$ 33 \mathrm{mmHgM}$

- $\quad$ NYHA Class: III/IV

- LVEF: $25 \%$ 


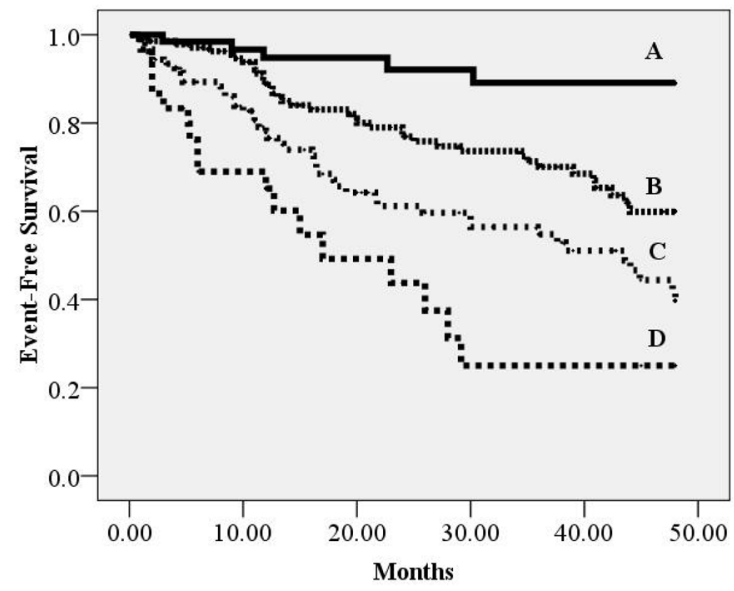

Figure 3.

Kaplan-Meier analysis for combined LVEF, NYHA class, resting $\mathrm{P}_{\mathrm{ET}} \mathrm{CO}_{2}$ and VE/VCO $\mathrm{VO}_{2}$ slope thresholds

\begin{tabular}{|l|c|c|c|c|}
\hline Group & Characteristics* & Subjects meeting criteria & Major Cardiac Events & Percent Event Free \\
\hline A & $\begin{array}{c}\text { No negative resting values } \\
\text { and positive VE/VCO } \\
\text { slope }\end{array}$ & 65 & 5 & $92.3 \%$ \\
\hline B & $\begin{array}{c}1 \text { Negative Resting Value } \\
\text { or Negative VE/VCO } \\
\text { slope }\end{array}$ & 136 & 38 & $74.0 \%$ \\
\hline C & $\begin{array}{c}2 \text { Negative Resting Values } \\
\text { and Positive VE/VCO } \\
\text { slope or } 1 \text { Negative } \\
\text { Resting Value and } \\
\text { Negative VE/VCO } \text { slope }_{2}\end{array}$ & 108 & 44 & $59.3 \%$ \\
\hline D & $\begin{array}{c}3 \text { Negative Resting Values } \\
\text { and Negative } \mathrm{VE} / \mathrm{VCO}_{2} \\
\text { slope }\end{array}$ & 30 & 17 & $43.3 \%$ \\
\hline
\end{tabular}

Log rank: $40.5, \mathrm{p}<0.001$

Negative Values:

- $\quad$ Resting PETCO2: $₫ 3 \mathrm{mmHg}$

- $\quad$ NYHA Class: III/IV

- LVEF: $25 \%$

- $\quad \mathrm{VE} / \mathrm{VCO}_{2}$ Slope: 236.0 
Table 1

Subject Characteristics

\begin{tabular}{|c|c|}
\hline Variable & Value \\
\hline Age (mean in years) & $58.6 \pm 13.7$ \\
\hline Sex (percent male/female) & $72.0 / 28.0$ \\
\hline NYHA class (percent I/II/III/IV) & $13.3 / 42.2 / 42.2 / 2.3$ \\
\hline HF etiology (percent ischemic/non-ischemic) & $50.1 / 49.4$ \\
\hline LVEF (mean in percent) & $28.0 \pm 8.5$ \\
\hline Resting $\mathrm{P}_{\mathrm{ET}} \mathrm{CO}_{2}$ (mean in $\mathrm{mmHg}$ ) & $34.3 \pm 4.0$ \\
\hline Resting VE/ $\mathrm{VCO}_{2}$ & $43.2 \pm 11.3$ \\
\hline Beta-blocker (percent yes) & 58.4 \\
\hline ACE inhibitor (percent yes) & 81.3 \\
\hline Diuretic (percent yes) & 87.4 \\
\hline Peak $\mathrm{VO}_{2}\left(\right.$ mean in $\left.\mathrm{mlO}_{2} \bullet \mathrm{kg}^{-1} \bullet \mathrm{min}^{-1}\right)$ & $14.5 \pm 5.6$ \\
\hline Peak $\mathrm{VO}_{2}$ Percent Predicted (mean \%) & $56.3 \pm 19.1$ \\
\hline $\mathrm{P}_{\mathrm{ET}} \mathrm{CO}_{2}$ at ventilatory threshold (mean in $\mathrm{mmHg}$ ) & $37.0 \pm 4.7$ \\
\hline $\mathrm{P}_{\mathrm{ET}} \mathrm{CO}_{2}$ at peak exercise(mean in $\mathrm{mmHg}$ ) & $33.5 \pm 5.6$ \\
\hline $\mathrm{P}_{\mathrm{ET}} \mathrm{CO}_{2 \text { Delta }}($ mean in $\mathrm{mmHg}$ ) & $2.7 \pm 2.6$ \\
\hline $\mathrm{VE} / \mathrm{VCO}_{2}$ slope (mean) $)^{£}$ & $36.4 \pm 8.7$ \\
\hline \multicolumn{2}{|l|}{ Normal Resting PETCO2: 36-42 mmHg } \\
\hline
\end{tabular}


Table 2

Cox Multiple Regression Analysis for Resting Variables

\begin{tabular}{|l|c|c|}
\hline Variable & Chi-square & p-value \\
\hline NYHA Class & 28.7 & $<0.001$ \\
\hline Variable & Residual Chi-square & p-value \\
\hline LVEF & 21.7 (Univariate chi square: $27.3, \mathrm{p}<0.001$ ) & $<0.001$ \\
\hline Resting $\mathrm{P}_{\mathrm{ET}} \mathrm{CO}_{2}$ & 14.1 (Univariate chi square: $27.2, \mathrm{p}<0.001$ ) & $<0.001$ \\
\hline Age & 0.51 (Univariate chi square: $0.93, \mathrm{p}=0.34$ ) & 0.47 \\
\hline HF etiology & 0.07 (Univariate chi square: $0.26, \mathrm{p}=0.68$ ) & 0.80 \\
\hline
\end{tabular}

